Historic, Archive Document

Do not assume content reflects current scientific knowledge, policies, or practices. 

RETURN TO POHOLOGY

SECTION OF NOWELCLATURE.

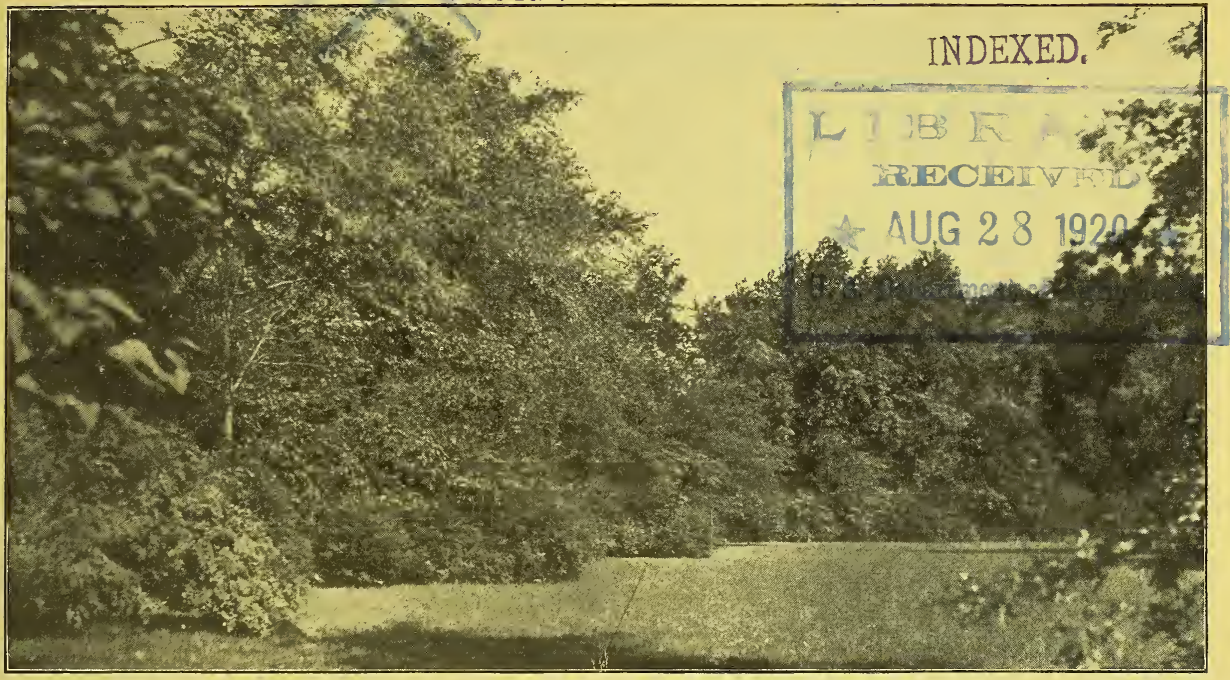

One of Our Plantings of simall Trees and Shrubbery.

\section{JAMES KING NURSERY}

ELMHURST AND WHEATON, ILL.

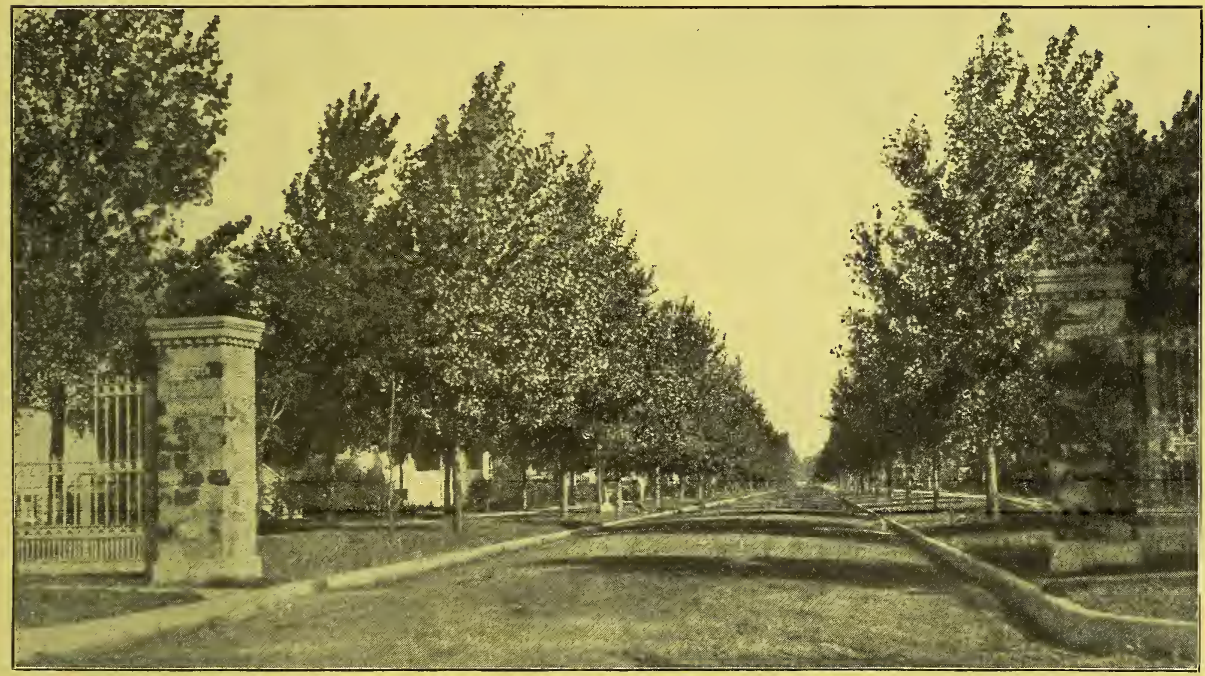

Thos. F. Fulbert's Subdivision in Oak Park, 2,040 Shrubs 648 Carolina Poplars. Planted By Us in Fall of 1904. 


\section{INDEX.}

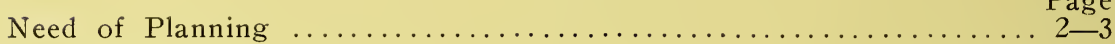

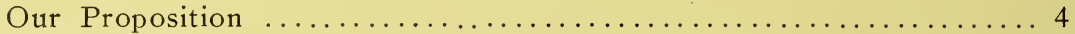

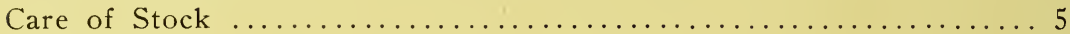

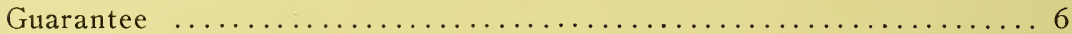

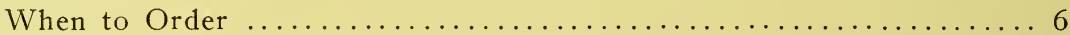

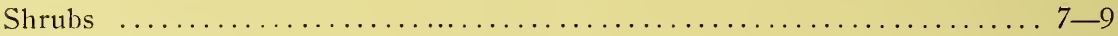

Hardy Climbers ................................... 9-10

Shade and Ornamental Trees ..............................

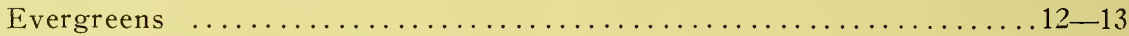

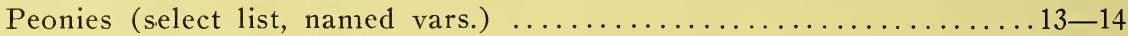

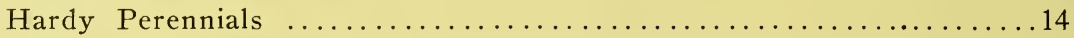

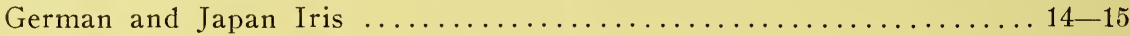

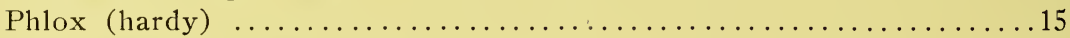

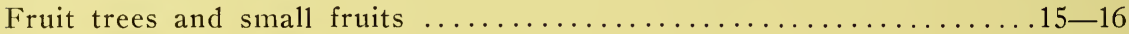

The nurseries at Elmhurst are about half way between the Chicago \& Northwestern Railway and the Aurora \& Elgin Electric. Entrance on Arlington Avenue. At Wheaton, on Chicago Avenue (Batavia road) just west of the A. E. \& C. Electric (Chicago Avenue station) adjoining city limits.

\section{JAMES KING NURSERY.}

Horticulturists and Landscape Gardeners.

Elmhurst and Wheaton, Illinois.

Phones-Elmhurst 102-M

Established 1890.

-Wheaton 298. 


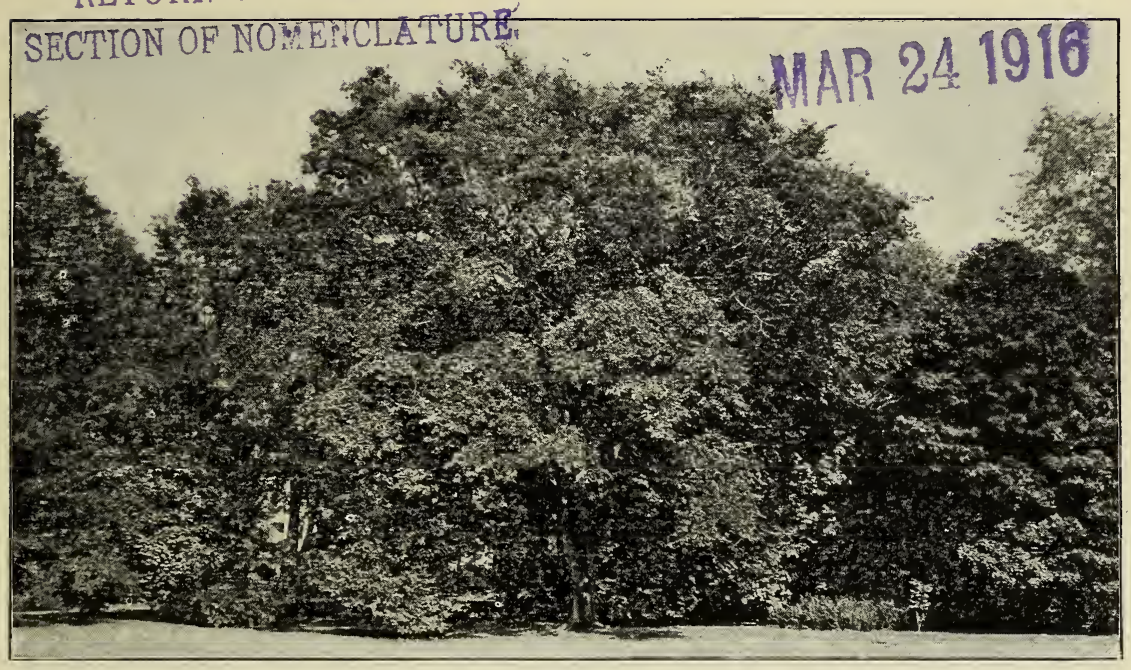

\section{American White Elm.}

The center of this group shows one of the finest specimens of this noble tree in Elmhur;t, but we have to go to New England to see it in its glory. When planting trees do not seek immediate effect, exclusively, but also use those that are still enhancing in beauty long after the fast growers are exhausted.

A Garden is the Purest of Human Pleasures. It is the greatest Refreshment to the Spirits of Man; without which, Buildings and Palaces are but gross Handyworks; and a Man shall ever see that when Ages grow to Civility and Elegancy, Men come to Build Stately sooner than to Garden finely; as if Gardening were the greater Perfection.-Bacon.

The business man of this age is particularly in need of the "greatest ReIreshment to the Spirits" that can be provided him. He realizes more and more that his capacity for continued work depends upon his opportunities for relaxation and healthful diversion outside of business hours. A constant mental and physical wearing out without a compensating building up inevitably fore-shortens life. But the most natural and pleasantest place for him to seek this revitalizing force is at home; hence the irrefutable and appealing argument for trees aild shrubs and gardens, which are the "greatest Refreshment" because they are Nature itself, the inspiration of every art.

For this reason we believe that the commodity we are dealing in is a necessity of life for business men, and that its money value (eliminating all sentiment) is measured by from twenty-five to fifty per cent of the productive capacity of those who possess it. To most people it is priceless, and the idea of a money valuation is unthinkable.

The exterior appearance of a house and grounds without foliage and flowcrs never changes. When the same scene has greeted the eyes for some thousands of times a year for many years an inexplicable restlessness and dissatisfaction is felt. 


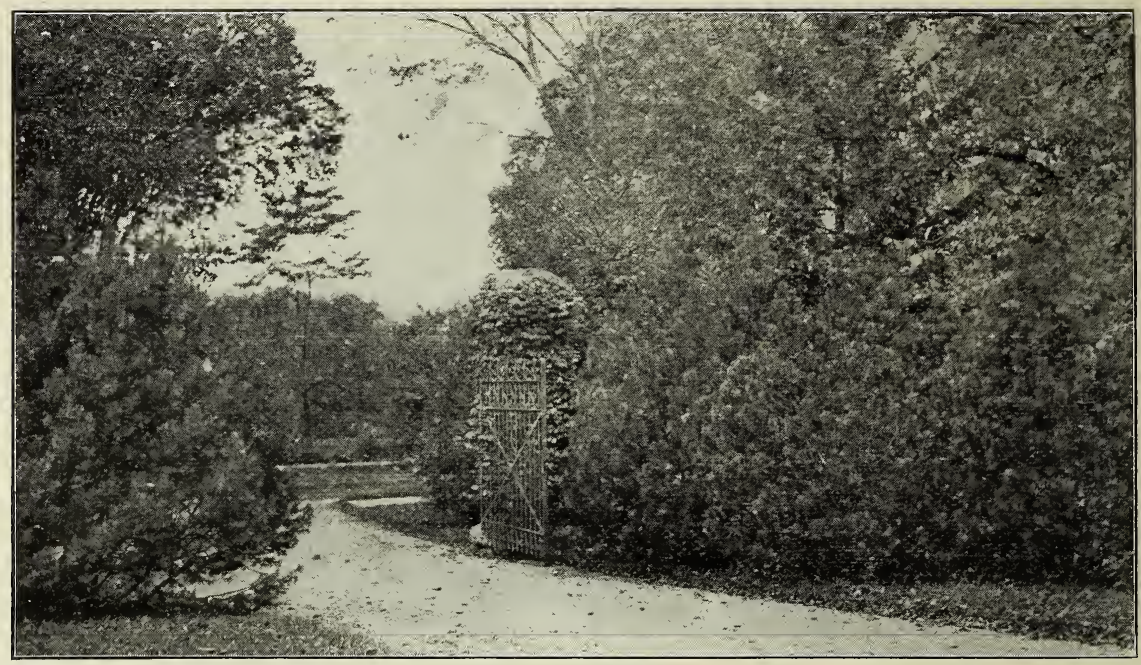

Pinus Mugho, Dwarf Pine-Fine in combination with tall shrubs and dwarf growing trees. Here are some good specimens of our stock on each s.de of the gateway.

But at the home where all parts of the grounds have been tastefully planted and the stiff foundation lines of the house appropriately broken, the picture from every window is a new one, the house is in a new setting from every angle of approach, and all these pictures are constantly changing from week to week and from season to season in successive periods of foliage, flowers, and fruit. Snows, rains, dews, frosts, and degrees of each bring out new beauties in a truly "infinite variety." You will find living here a man who can endure and enjoy the business "struggle for existence," whose friends are glad to call and enjoy his place with him, and whose children are interested in the beauties of nature at an age when that influence means much.

\section{THE NEED OF PLANNING.}

House grounds and college grounds, private gardens and public parks, may be senselessly as well as ineffectively arranged but they may still be glorified by yellow and purple leafage. In short, " the world is still deceived with ornament."-Charles Eliot.

Any property is planted but once under ordinary circumstances. Hence a man comes up against his one and for-all-time planting proposition without any previous experience. In most other matters of his home life he learns by trial that one method or one kind is better than another, and he changes without great inconvenience or expense. But experimenting with nature is a very expensive and disappointing experience.

Suppose a planting has been made without careful thought or skilled supervision and having grown for three or four years is just beginning to lose its "new" look. The owner has taken an interest in it and has been reading about matters of arrangement for color effects and to give breadth, and treatment of light and shade, permanent and temporary effects; and he comes to understand that certain of the trees and shrubs are entirely out of place, that others are not of suitable varieties and perhaps that the fruit is worthless. The result is that part of the planting is put back to where it started. 


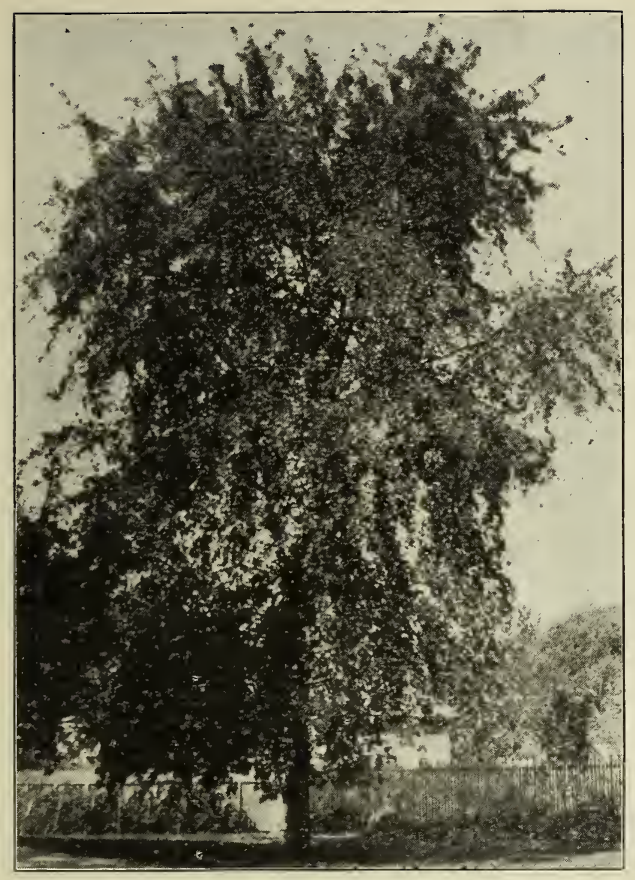

Weir's Cut-leaved riaple.

A ripid growing maple of drooping habit, with deeply cut foliage. A very graceful tree frir the lawn.

The location of the residence and other buildings is another vitally important matter seldom realized as such until too late. Here again the average inan who builds but once in the country is confronted by a new problem, whicn if carelessly solved means a life-time of regret. One man recently said to us, "It is worth all.I paid simply to have my barn located where it is insteac of where I intended to place it."

A house put down in the middle of a moderately sized estate spoils all breadth of lawn, makes the approaches awkward, and frequently forces them to the wrong side of the building to suit the contour of the grounds. There are wonderful possibilities in locating a house, and every piece of land offers new problems which if happily solved add vastly to the enjoyment of the place. As in every line, an expert should be consulted and the location of buildings, drives, entrances, etc., worked c:ut in his plan for the whole grounds in order to have an harmonious whole.

\section{OUR PROP(,SITION.}

Our services as landscape gardeners are incidental to those as nurserymen and are for the convenience of our castomers. We offer them to person: and corporations desiring to lay out and improve suburban and country estates, subdivisions, public parks, gardens, etc. The combination of landscape gardening with the nursery business is perfectly natural and much to the advantage of the customer. It is a saving in time and money over the plan ot employing a professional landscape gardener and in addition paying for the nursery stock, labor, freight, and other expenses. 


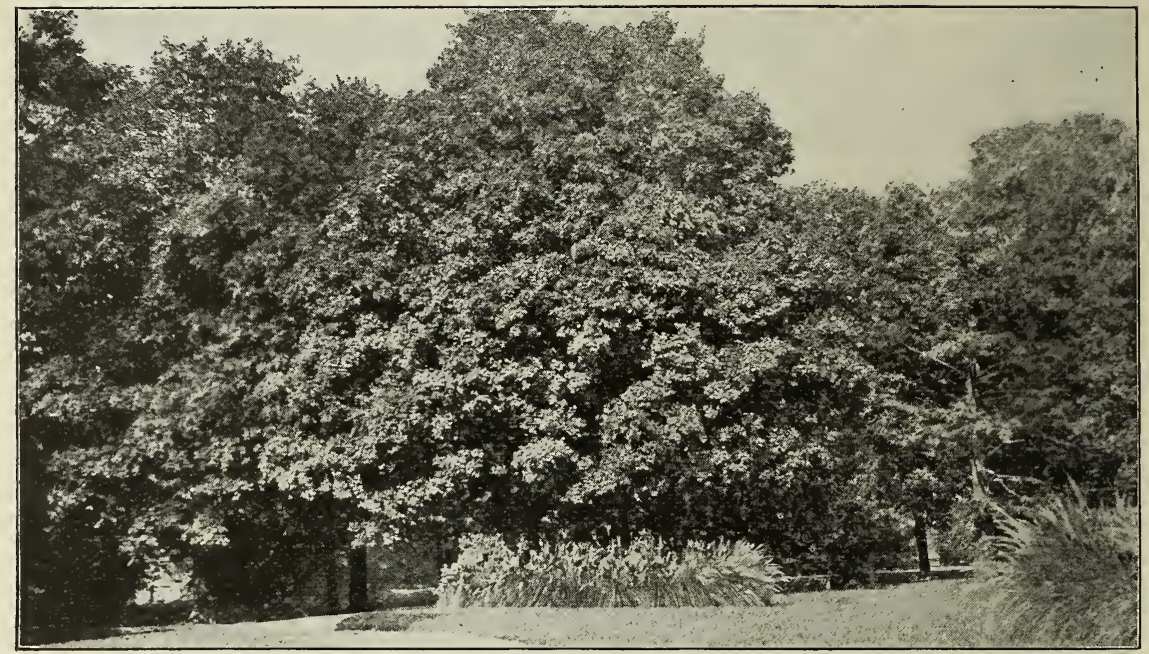

Acer Flatanoides.

Norway Maple. One of our most beautiful shade trees, of a sturdy, enduring habit, broad round form, and deep green foliage-a choice tree for either street or lawn. We have a very fine stock of this maple.

Our proposition to our customers depends upon the situation of the property and the preference of the owner. A consultation on the ground is usually the first step and if resulting in an order, or if necessitating the loss of but an hour or so there is no charge. With an order amounting to fifty dollars or more, if desired, we will include a plan without additional charge. If our services or a plan are required without any nursery stock, services will be charged for at the rate of $\$ 1.50$ per hour including traveling time between $8 \mathrm{~A}$. M. and $6 \mathrm{P}$. M., and expenses; the cost of a plan will vary with the amount of work required on it from $\$ 10$ upward.

In case of an order for nursery stock, the rate depends upon the following circumstances,-(1) shipped f. o. b. the nursery; (2) shipped f. o. b. the nursery and planted under our supervision but not by our labor: (3) delivered, planted, and guaranteed by us according to plan or not. The rate on (1) depends upon the size and variety of the stock; on (2) the same as (1) plus charge for services in supervision at rate given above; on (3), a rate to include all charges of transportation, labor, supervision, and guarantee, with a reduction if no guarantee is given.

If the stock receives reasonable after-care a guarantee is an unnecessary expense. By above scheme, our charges will be seen to vary with the amoun of time and labor required of us in the planting, if the value of the stock is the same in each case; and we strongly advise proposition (2) as the most economical and satisfactory to all concerned.

We do not contract for grading, draining, road-making, etc., but will gladly assist our customers in finding responsible parties for the work. 


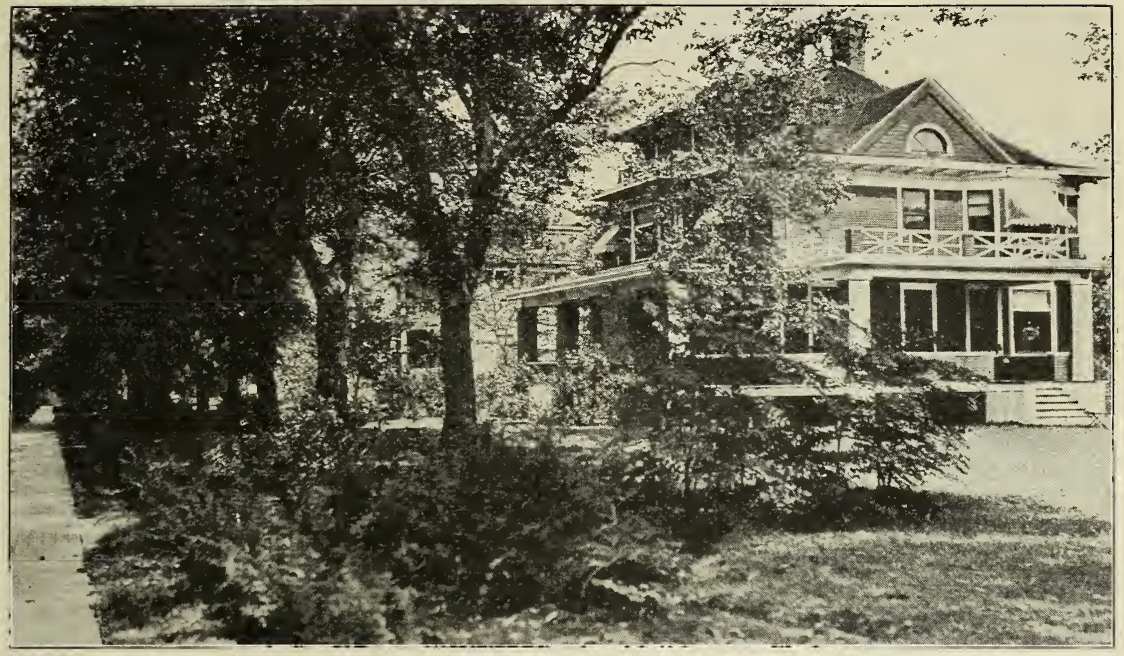

One of our more recent plantings in Elmhurst, showing a front hedge of Thunberg Barberry, a clump of Aralia Spinosa to the right, and various informal masses under the trees and around the porch.

\section{CARE OF STOCK.}

We do not believe in influencing anyone to undertake an extensive improvement of his grounds out of all proportion to the other improvements or to his means, because we do not want our plants to suffer through neglect or unfavorable conditions and make a poor showing. We find that people are always ready to place first blame on the stock. The difference between trees and shrubs thriving and merely existing, in the course of five years amounts to a difference of two or three years in growth and a vital difference in health.

The following conditions are essential to the best results of a planting. If they obtain, the stock will continue healthy, and when healthy will give its best in foliage, flowers, fruit, and habit of growth.

Grading should of course be finished before planting is begun, and if the soil is naturally poor, enough good soil should be provided to fill holes larger than are necessary to contain the roots of the plants.

For the first two years at least, all grass and weeds should be kept out of the beds of shrubbery and from around the base of the trees, and the soil loosened frequently during the summer to a depth of three inches. The best way is to prepare the beds for shrubbery before planting, by spading in all vegetation together with fertilizer and good soil, if needed. After the second year of this treatment the shrubs will keep the weeds out themselves.

All plants should be mulched during the first two winters with three to five inches of a mixture of straw and manure for a space somewhat larger than the hole dug to receive the plant; beds of shrubbery should be mulched solidly. A mulch kept on during the summer will take the place of watering and loosening the soil, except in a very dry summer.

Water from June to September every week or two in sufficient quantity to penetrate to all the roots; make no exception for rainfall in sandy soils. Do not water a little every day or two, as it wastes time and water and sours the soil. 
Trees two inches or more in diameter should be wrapped in burlap to a height of six or eight feet during the first two summers to protect the bark from the hot sun and from borers while the flow of sap is slow from the process of transplanting.

Pruning of trees and shrubs is needed at the proper season a few years after planting and at intervals in order to remove dead wood and keep the plant in its best possible condition. The sort of pruning needed depends upon the variety and purpose of the plant. Large wounds on a tree should be covered with lead paint.

Spraying of fruit trees, specially apples, is absolutely necessary to the production of good fruit. It is a little bother and expense and must be done at the proper time, but the results are remarkable. We do not undertake this for our customers but are glad to advise them in this connection.

\section{GUARANTEE.}

The matter of guaranteeing nursery stock to live is one that is productive of considerable misunderstanding and sometimes of ill-feeling in our business, and we wish clearly to state our attitude in regard to it.

A moment's reflection will convince anyone of the unreasonableness of expecting us to guarantee, (1) stock that we do not plant ourselves, or (2) any stock unless at a liberal advance in price. There are too many circumstances entirely beyond our control that might cause a considerable loss. On the other hand, if there is no guarantee our customer will take a more active interest in the welfare of the plants and will take such measures as may be necessary for their protection from extreme drought, poorness of soil, injury by sun, borers, fire, animals, etc. In so doing he will save the loss of a year's or more growth on what would have failed and the inconvenience of another planting. The few things that will die under these circumstances can be purchased for much less than the cost of a guarantee on the whole order.

When a guarantee is given it must be agreed by the customer that the stock shall receive reasonable care, although it is no less to his advantage to do all he can to aid and hasten the slow processes of nature. We retain the privilege of replacing dead stock either in the fall or spring before the growing season following the one during which the stock died. If we are not notified before the following growing season of failures of guaranteed stock we shall not be liable in any way for failure to comply with above agreement.

\section{WHEN TO ORDER.}

As an undertaking of any extent cannot be discussed, planned, and completed off-hand, we want to emphasize the importance of planning for work a whole season in advance if possible of the next planting season. This will permit of careful and thoughtful plans and early work; the importance of the latter of which cannot be overestimated. Fall planting can be done as soon as the foliage falls, and the soil will have time to settle well about the roots and a root-growth will take place before the ground freezes to that depth. Successful planting can be done, however, as late as the soil is workable. Spring plantings should be made soon after the ground opens up and is workable, in order to give the stock the benefit of the early rains.

When we are called upon to plan the disposition of the buildings in connection with the grounds (the ideal arrangement), little planting can be done until the buildings and grading are completed, which gives ample time to complete plans for our work.

Permit us to repeat a word in regard to planting the slowest growing plants (trees) as soon as a property is purchased. There is a limit to the size of a shade tree that can be moved successfully (unless at great cost), and some varieties cannot be moved except when small. Fruit trees give best results when planted young, requiring four or five years to give any noticeable yield of fruit. Shrubs take a few years to give their finest effects: the best trees require a lifetime. 


\section{HARDY FLOWERING SHRUBS.}

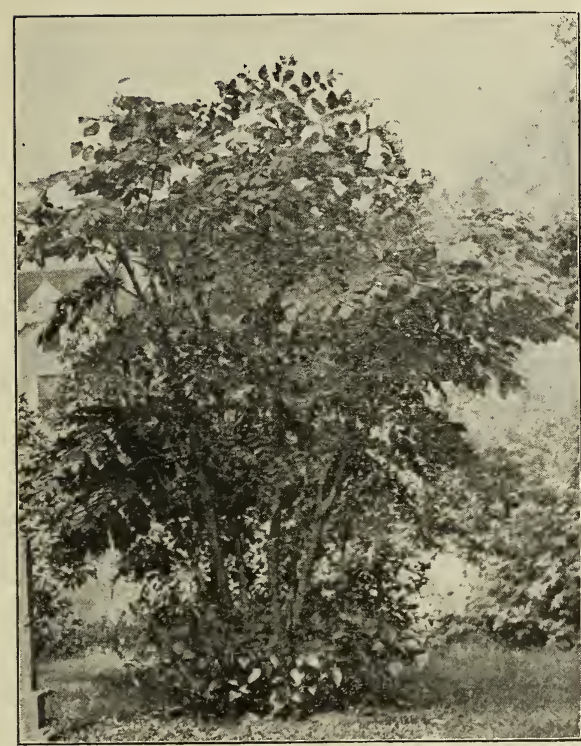

ARAIIA, SFINOSA

Assorted Shrubs. - Strong stock, suitable for the trying climate of Chicago. Large enough for immediate effeci, mostly three to five ft. high with a few dwarfer sorts two to three ft. 50c cach; $\$ 5.00$ per dozen, except where noted.

A-Amorpha Fruticosa. False Indigo. Grows 6 to 10 feet high, with compound leaves, containing 10 to 20 bright green leaflets, and slender spikes of deep violet-blue flowers in June.

A-Aralia, spinosa. Small trees, desirable in producing a tropical effect, as their large, pinnate leaves are very attractive. Prickly stems. Spikes of snowy white flowers in August. 4-6 ft., 75 cents.

BERBERIS VUIGARIS (common Barberry).-A showy shrub, covered in the autumn with brilliant red fruit.

B-Purpurea. Purple leaves. Very distinct. Contrasts finely with yellowleaved shrubs.

B-Thunbergii. "A low bush of dense growth and shining foliage. Fine for hedges.

B-Ilicifolia. Holly-Leaved Barberry. Large dark green leaves, remaining on the plant until late winter.

CORNUS SANGUINEUS-Red-Stemmed Doo Wood. Grows six or eight feet high. In winter the branches are bright red; clusters of white blosisoms in May.

C-Elegantissima Variegata. One of the finest variegated shrubs; of rapid growth; the leaves are broadly mar. gined with white, while some are entirely white.

C-Spaethii Aurea. While the variegation in elegantissima is white, in this variety it is pale yellow. One of the finest of recently introduced shrubs.

C-Siberica. Red stems in winter. This and the sanguinea have white flowers in June, and make large shrubs.

C-Mas. Cornelian Cherry. A small tree, producing clusters of bright yellow flowers early in spring, before the leaves, followed by red berries.

CYDONIA-Japonica. Scarlet Japan Quince. Has bright scarlet crimson flowers in great profusion in the early spring; one of the best hardy shrubs.

\section{CEPIAIANI"IUS OCCIDENTAIIS-} Button Bush. Makes a dense, elegant growth, studded with large clusters of white, fragrant, ball-like flowers in July.

DEUTZIA-Pride of Rochester. Double white, tinged with rose; superior in size of flowers and profusion of bloom.

D-Iemoineii. Flowers pure white, borne on stout branches, which are of upright growth. Habit dwarf and freeflowering. A decided acquisition.

DI.ZAGNUS ANGUSTIF OLIA-Russian Olive. A very hardy and handsome small tree. The leaves are willowlike and a rich, silvery white. Blooms in June.

EUONYMUS-Burning Bush. A tall growing shrub, with clusters of scarlet three-lobed seeds. A small tree.

EXOCIORDA GRANDIFIORA-Pearl Bush. Long, loose sprays of pure white flowers open in May, in such profusion as to give a very rich effect.

FORSYTIIA SUSPENSA-Golden Bell. Bright yellow bell-shaped flowers; very early: of drooping habit.

$\mathbf{F}$ - Fcrtuneii Fortunes Forsythia. Growth upright, foliage deep green, flowers bright yellow.

F-Intermedia. Flowers bright golden; Foliage glossy green. Very attractive in early spring.

F-Viridissima. The flowers are a little deeper yellow than in other sorts. Not quite so hardy.

FYDRAIGEA-Panticulata Grandiflora. A fine shrub, flowers white, in great panicles 8 inches long; in August and September, when very few shrubs are in bloom

F-Arborescens Alba Grandiflora. Upright growing 4 to 8 feet high, with bright green leaves and flat-topped trusses of white flowers in mid-summer.

HIBISCUS SYRIACUS-Althea. Easy of cultivation and blooms in the autumn, when there are but few shrubs in flower. Double white or pink.

IFRRIA-Japonia. Smooth green bark and orange-yellow, double flowers. An old-fashioned favorite.

IIIAC, PURPIE-The old species of our grandmothers' gardens, so universally loved.

I-Alba. The old white lilac of New England. 


\section{HARDY FLOWERING SHRUBS.}

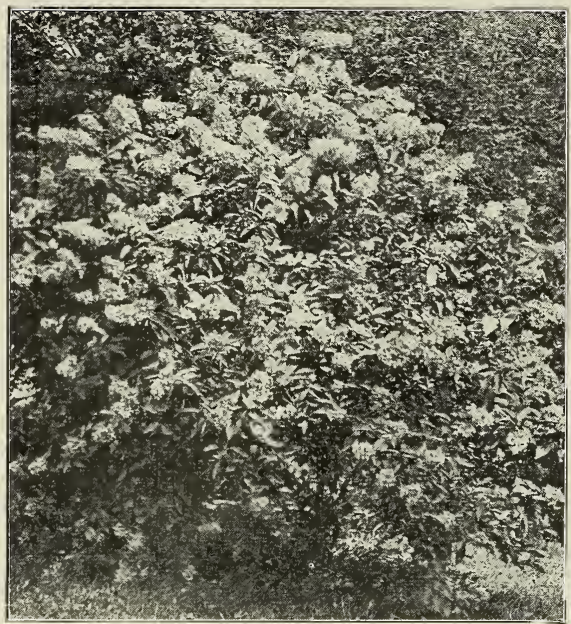

Hydrangea

I-Japonica. Tree Lilac. A vigorous grower; forms a medium-sized tree, and blooms in loose clusters of creamy white flowers a month later than other lilacs. $75 \mathrm{c}-\$ 2.00$.

I-President Grevy. A beautiful blue; individual flowers very double and large; the panicle is magnificent. 75c.

I-IMarie Iegrave. Large panicles of white flowers. Valuable for forcing.

I-Fersica-Persian Lilac. From 5 to 7 feet high, with small foliage and reddish purple blooms.

I-Persica Alba. White Persian Lilac. Delicate white fragrant flowers, shaded with purple.

I-Persica Iaciniata. Persian CutLeaved Lilac. Deeply cut leaves and reddish purple flowers.

I-Villosa. A Japanese Lilac, blooms 2 or 3 weeks after others, in large spreading panicles of pale lilac.

I-Charles $\mathbf{x}$. A strong, rapid-growing variety, with large shining leaves; trusses large, rather loose. 75c.

I-Rothomogensis Var. Rubra. Rouen Lilac. A distinct hybrid variety, with reddish flowers; panicles of great size and very abundant.

I-Rubra de IJarley. Rich, rosy purple flowers. Blooms much younger than the common purple.

IIGUSTRUIM-Ibota-Japan Privet. Native of Japan. Flowers white, fragrant and produced in profusion.

Ir-Vulgare. Box-Leaved Privet. With short, thick, dark green leaves. Fine for hedges.

I-Regelianum. Handsome shining foliage and horizontally spreading branches.

I-Amurense. Very hardy, with dark green leaves, which hold nearly all winter. White flowers in June.
IONICFRA, TARTARICA-U p r I g h Honeysuckle. One of our best shrubs. The flowers are red and pink, and delicately fragrant.

I-Worrowii. A fine variety from Japan; valuable for its handsome red fruit.

PRUNUS PISSARDI-Purple-Leaved Plum. A fine purple-leaved tree. The young sprouts are bright crimson, changing to a dark purple.

P-Triloba. Double Flowering. Flowers resemble the Flowering Almond; of a delicate pink color, and closely set on long, slender branches.

P-Japonica Fubra rlena and Alba Flena. Flowering Almond. A dwarf shrub, bearing in May, double, roselike flowers.

PFITADETFHUS CORONARIUS. Syringa. A well known shrub, with pure white, highly scented flowers.

P-Aurea. Golden Leaved Syringa. Medium size of golden yellow foliage the entire season.

P-Grandifiorus. Large-Flowered Syringa. Slightly fragrant; a strong, tall shrub.

P-Iemonineii Erectus. Lemonies' Syringa. A charming variety of upright growth; flowers small, yellowish-white, fragrant, completely covering $t h e$ plant.

PTIIFA TRIFOIIATA-Hop Tree. A dwarf-growing, shrub-like tree, bearing large clusters of seeds resembling hops.

RFUS TYFFINA-Staghorn Sumach. Forming a small tree, 10 to 15 feet high.

$\mathbf{R}$-Typhena Iaciniata. Cut-Leaved. Stag Horn Sumach. A fine form, with deeply-cut plume-like foliage.

R-Iaciniata. Cut-Leaved Sumach. Moderate size, with deeply cut leaves resembling fern leaves.

RHODOTYPUS KRERIOIDES. White Kerria. An attractive shrub of medium growth, with good foliage and large, single white flowers late in May.

RIBES AUREUM- $\mathrm{Y}$ e $110 \mathrm{w}$ Currant Flowers yellow; very fragrant and early.

R-Cordonii. One of the finest; flowers red and yellow.

ROSA EUBIGINOSA-Sweet Brier. A single-flowered rose, prized for the delightful fragrance of the foliage.

$\boldsymbol{R}$-Rugosa. Japanese Rose. A valuable rose, with dense glossy leaves. The large, single flowers are bright rosy red or white, and are followed by scarlet fruit.

R-Wichuriana. Japan Trailing Rose. Shoots 10 to 15 feet long; small glossy foliage; abundant clusters of pure white, single roses.

R-Crimson Rambler. A vigorous grower. The flowers grow in panicles each carrying 20 or 30 blooms of a bright, vivid crimson.

R-IMad. Irevavasseur (Baby Rambler). A dwarf Crimson Rambler, hardy, vigorous and perpetual flowering. of a crimson red color, and borne in clusters. 


\section{HARDY FLOWERING SHRUBS.}

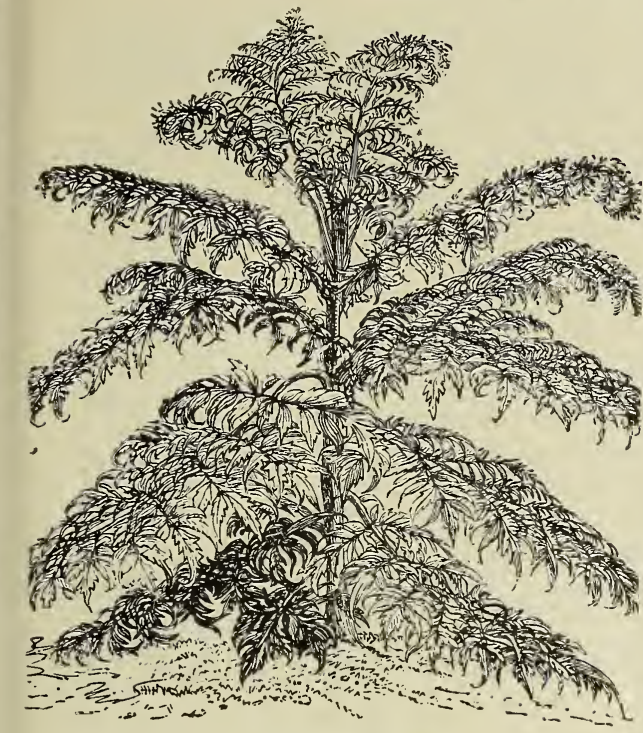

Rhus Laciniata

R-Maman Ievavasseur (Pink Rambler) Similar in all respects to Crimson Baby Rambler, but of a clear brilliant pink and very freely produced.

$\mathbf{R}$ Dorothy Perkins. A Climbing Rose. Clear shell-pink, flowers borne in clusters; full and double, with crinkled petals.

R-Multiflora Japonica. Large clusters of fragrant, snow-white blossoms followed by red seed-vessels. Of strong, quick growth, and perfectly hardy.

SAMBUCUS AUREA-Golden Elder. A handsome variety, with golden-yellow foliage; a valuable plant for enlivening shrubberies.

S-Iaciniata. Cut-Ieaved Elder. A valuable variety, with elegantly divided leaves; one of the best cut-leaved shrubs.

s-Variegata. Variegated-Leaved. Foliage mottled with yellow and white; one of the best variegated leaved shrubs.

s-Racemosa Plumosa. Leaves beautifully cut and drooping, giving the plant a unique effect.

s-Nigra. Black-Berried Elder. of strong growth, with purplish-black berries in September.

SPIREA VAN HOUTII-The finest shrub in the collection. Early June, the plant is covered with a mass of large white flowers, presenting a beautiful appearance.

s-Opulifolia. They make st ro $\mathrm{ng}$ growth, although their branches droop when laden with white flower umbels in June. For backgrounds they are very valuable.

S-Var. Aurea. Of similar habit. Leaves bright yellow in spring, changing to golden bronze in fall.
S-Frunifolia Plore Pleno, The earliest to bloom. Very graceful, the branches being covered thickly with small, double white flowers.

s-Anthony waterer, A fine dwarf Spiraea bearing dark crimson flowers all summer.

SNOW ERPRY. Small pink flowers, and beautiful clusters of snow-white berries remaining on the bush very late.

S-Vulgaris. Red-Fruited. A shrub of very pretty dwarf habit. Fruit purple; hangs all winter.

TAIMARIX - Africana Small, needle-like leaves and spikes of delicate pink flowers, in May.

T-Indica. Pink flowers in longer, more wandlike sprays. Foliage is olive green.

VIEURNUIM OPUIU S STFRILISSnowball. Very beautiful and popular; flowers snowy white, borne in large balls in June.

v-Ficatum. Japan Snowball. Somewhat tender. Of moderate growth, with heads of pure white flowers. Its habit is better, flowers whiter and more delicate than the old variety.

v-Acerifolium. Maple-Leaved. Has slender, upright branches, 3 to 5 feet tall, with maple-like foliage and creamy white flowers in late spring, followed by black berries.

v-Dentatum. Arrowwood. A bushy shrub with bright green, heart-shaped leaves, which fade into rich purple and red. Creamy white flower's in flat cymes in late spring.

v-Opulus. Cranberry Tree. White flowers in summer, with attractive red berries similar to cranberries in autumn.

v-Iantana. Farly White LantanaLeaved. A large, robust shrub, with soft, heavy leaves, and large clusters of white flowers in May, succeeded with red fruit; retains its foliage very late.

WIIGEIIA-IROSEA-A variety bearing beautiful and showy rose-colored flowers in June; hardy and easy of cultivation.

W-EVA IRATIRE-F l o w e r s brilliant crimson; a beautiful, clear shade, and continuing a long time.

FARDY CIIMBERS, 50c each;-\$5.00 dozen.

ARERIA QUINATA-Hardy, climbing shrub, with fine foliage, dark purple flowers.

AMPRTOPSIS-Veitchii. Clinging to smoothest surfaces; colors finely in autumn, most beautiful climber.

ARISTOIOCEIA SIPFO-Dutchman's Pipe. A magnificent hardy vine of rapid growth, with very large, heartshaped leaves and brownish flowers, resembling a miniature pipe.

CEIASTRUS SCANDENS-Bittersweet A native climber, with handsome, glossy foliage, and large clusters of beautiful, orange-crimson fruits, retained all winter.

CIFMATIS PANICULATA-Of robust climbing habit, growing 12 feet high, with an abundance of white fragrant flowers. It is perfectly hardy, native of Japan. 
CLIMBERS.

JAE O IICA DOLICI OS - I $u$ d z u Vine, f a s t g $\mathrm{r}$ o $\mathrm{w}$ i $\mathrm{n}$ g vine, 15 to 25 ft. in a sing le season from established roots, fine for arbors, porches, etc.

\section{EUONYMU} RADICA NS -One of the finest evergreen vines. with small, $\mathrm{r}$ ic h green foliage a $n$ d pink fruits.

II 0 N $\mathbf{I}$.

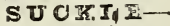
$\mathrm{B}$ e $1 \mathrm{~g}$ i c a Blooms a 11 $\mathrm{s} u \mathrm{~m} \mathrm{~m}$ e $r$. Red and yellow fragrant flower

II $O$ N $\mathbf{Y}$ SUOKI I H a 11 e ana. Japan. Vigorous grower. Flowers y e $110 \mathrm{wish}$ w h i t e, exc e e d i n g-

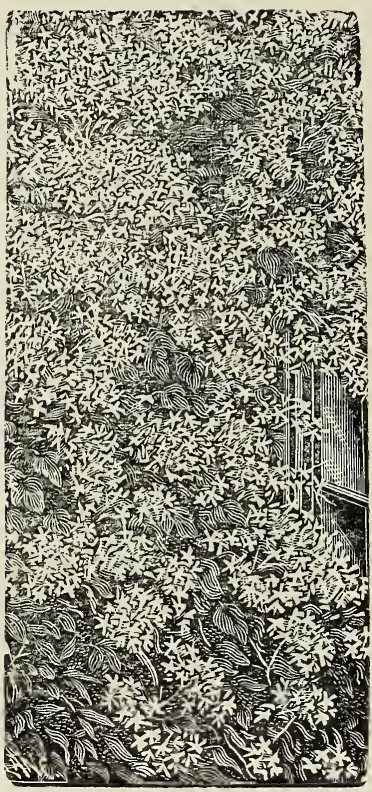

Clematis Faniculata. ly fragrant

and freely produced all summer.

IYCIUIM CEINENSE-Matrimony Sometimes trained as a shrub. Purple-flowered and showy-fruited. Extra vigorous in growth.

PERIFIOCA GRAECA-Silk Vine. An exceedingly rapid grower, with shining, long narrow leaves, and clusters of purplish brown blossoms.

WISTARIA-Strong grower, desirable for trellises, porches, etc. A free bloomer and handsome flower; light purple.

\section{CLIMBING ROSES SEE PAGE -}

\section{SHADE AND ORNAMENTAL TREES.}

We have a choice as sortment of well grown shade trees in our grounds at Elmhurst. Some varieties up to 20 feet in height.

Prices as follows, except where noted: $6-8$ ft., 75c; $8-10$ ft., $\$ 1.00 ; 10-12$ ft., $\$ 1.50 ; 12-14$ ft., $\$ 2.00$ each. 14-16 ft., \$2.50. Per dozen take ten times the single rate for any given size.

ACER DASYCARPUM-S of $t$ Maple. Form, tall and graceful; a fast growing variety, and therefore desirable where trees of rapid growth are needed.

A-Platanoides. Norway Maple. A native of Europe. Large, handsome tree, of rounded form, with broad foliage. Its compact habit and vigorous

\section{SHADE TREES.}

growth render it one of the most desirable for the street or lawn. 6-8 $\mathrm{ft}$, $\$ 100 ; 8-10$ ft., $\$ 2.00 ; 10-12$ ft., $\$ 2.50$; $12-14$ ft., $\$ 3.00$.

A-Schwedlerii. Purple-Leaved Norway Maple. A new variety, with bronzy red or purple foliage; one of the most desirable trees of recent introduction. 6-8 ft., \$2.00; 8-10 ft., \$2.50; 10-12 ft., $\$ 3.00$.

A-Weirii Iaciniatum. Weir's Cut Leaved. A variety of the Silver Maple, with deeply cut leaves and graceful drooping habit.

A-Saccharinum. Sugar Maple. A well known native tree, of elegant pyrmidal form; its fine form and foliage make it desirable for street and lawn planting. 8-10 ft., \$2.00; 10-12 ft., \$2.50; 12-14 ft., \$3.00.

A-Rubruin. Red, or Scarlet Maple. Large tree, with spreading branches. The beautiful red flowers appear in late winter. In the fall, the leaves turn to the most brilliant shades of red and scarlet. 10-12 ft., \$2.50.

A-Polymorphum. Japan Maple. Growth slow and shrubby; foliage small, fivelobed, and changing to a lovely dark crimson in autumn. \$2.50.

A-Atropurpureum. Purple-Leaved Japan Maple. Foliage dark purple and deeply cut; very ornamental. The hardiest and best of the Japan Maples. Dwarf habit. \$3.00.

AFSCUIUS GTABRA-Horse Chestnut. A large-sized tree, of handsome, regular outline. In May it is covered with magnificent panicles of yellow flowers. $6-8$ ft., $\$ 1.00 ; 8-10$ ft., $\$ 1.50 ; 10-12$ ft.. $\$ 2.00$.

AIIANTIUS GIANDUIOSA-From Japan. A lofty, rapid growing tree, with long, elegant feathery foliage, exempt from all di eases and insects. One of the mo t distinct of ornamental trees. ['seful to prodice tropical effects.

AINUS GIUTINOSA-European or Common Alder. A remarkably rapid grower, reaching a height of from 30 to 40 feet. Foliage wedge-shaped. Suitable for moist situations.

A-I Iaciniata Imperialis. Imperial CutLeaved Alder. Of graceful habit, with large and deeply cut foliage: vigorous and perfectly hardy. One of the best lawn trees. 4-6 ft., \$1.00; 6-8 ft., $\$ 1.50$; 8-10 ft., \$2.00.

AMYMDAUS-Rosa Pleno. Large Double-Flowering Almord. A vigorons, beantiful tree, covered in May with double rose-colored blo $\approx$ soms, like small roses. 4-6 ft.. $\$ 1.00$.

BFT'UIA AIBA-White Birch. A graceful tree, with silvery bark and slender branches. Frect when young, bit after five years' growth assumes a drooping habit. $6-8$ ft., $\$ 1.00 ; 8-10$ ft., $\$ 1.50$; 10-12 ft., \$2.00.

CATAIPA SPECIOSA-A showy, rapid growing tree, with large. heart-shaped leaves, and clusters of white, fragrant flowers, early in July.

C-Bungei. Dwarf Catalpa. A small species that grows 5 to 6 feet high and twice as broad. forming a great bush. 3-4 ft., each, $\$ 1.00$. 


\section{SHADE AND ORNAMENTAL TREES.}

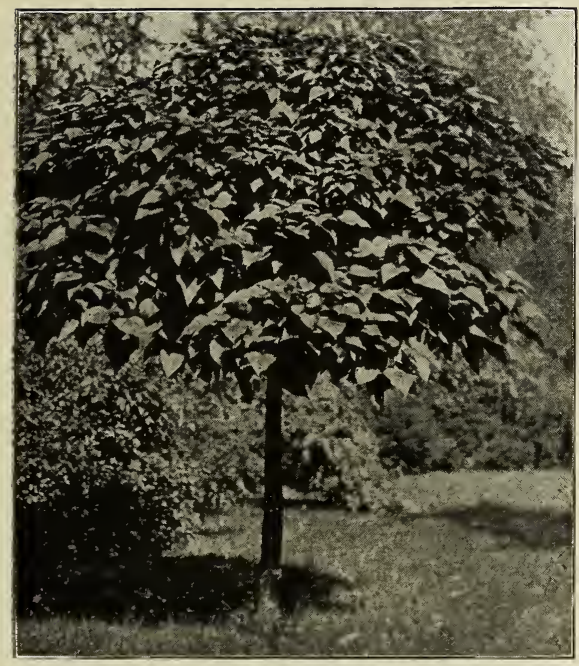

Catalpa Bungei

C-Bungei. Grafted on Speciosa. Forming large dome shaped heads. 8-10 ft. high, $\$ 2.00$ to $\$ \mathbf{3 . 0 0}$.

CERASUS AIBA PLENA-Large Double-Flowering Cherry. At the period of flowering in May, a remarkably beautiful and attractive tree. 4-6 ft., each, \$1.50.

C-Rosea Pendula. Japan Weeping Cherry. One of the finest weeping trees for lawns or small grounds. The slender branches fall gracefully to the ground; with rose-colored flowers. 5-6 ft., \$2.00.

CFRCIS CANADFNSIs-Red Bud. Very beautiful when in bloom. All the branches are covered with a mass of small red flowers early in the spring. 4-6 ft., $\$ 1.00$.

C-Japonica. Japan Judas Tree. Of medium size, rounded form, foliage deep shining green, flowers reddish purple. $3-4$ ft., $\$ 1.00$.

CRATAEGUS COCCINHA FIORA PIENo. Double Scarlet Thorn. A tree of fine habit, with rich, luxuriant foliage. Flowers large, of a deep crimson and very double. 4-5 ft., \$1.00.

C-Candida Pleno. Double White Thorn. Has double white flowers. A highly ornamental variety, on account of both foliage and flowers. 4-5 ft., \$1.00.

C-Crus Galli. A dwarf tree. Flowers profusely in May. White tinged red. 4-6 ft., \$1.00.

F A. G U'S FFRRUGINEA - American Beech. A native forest tree of slow growth. Uniformly symmetrical and handsome. 4-6 ft., \$1.00.

F-Incisa. Cut-Leaved Beech. A fine, erect, free-growing tree, with deeply cut foliage, like the fernleaf, a beautiful tree. 3-4 ft., \$2.00.

$\mathbf{F}$-urpurea. Purple-Leaved Beech. An elegant vigorous tree, growing 40 to 50 feet high. The foliage in spring is deep purple, and later in the season changes to crimson. 4-5 ft., $\$ 2.5 \mathrm{~J}$.

J-Nigra. Black Walnut. A fine tree of very large size and rapid growth, valuable for timber as well as for its fruit, and a handsome ornamental tree.

IIRIODENDRON TUIIPFERA-Tulip Tree. A magnificent native tree, of tall, pyramidal habit, with broad, glossy fiddle-shaped leaves of a light green color, and beautiful tulip-like flowers. 6-8 ft., \$1.50; $10-12$ ft., \$2.00.

MORUS TARTARICA-Russian Mulberry. A hardy, rapid grower, of a shrubby habit. Graceful in outline and form of leaf.

M-Tartarica Pendula. Teas Weeping Mulberry. Forms a perfect umbrellashaped head, with long slender branches drooping to the ground; very hardy. One of the prettiest small weeping trees. $\$ 1.50$.

PIATANUS OCCIDENTAIIS - Sycamore. A handsome tree, of rapid growth, with large foliage, and smooth, ash-grey colored bark.

P O P U I U S MONOITPRA-Carolina Poplar. Pyramidal in form and robust in growth; leaves, large, glossy, serrated, pale to deep green.

P-Boleana. Very compact, upright grower, resembling the Lombardy Poplar with leaves glossy, green above and silvery beneath.

P-Aurea. Golden Poplar. Has fine golden yellow foliage retaining its brilliancy throughout the season.

F-Alba. Silver Poplar. A tree of wonderful rapid growth, and spreading habit. Leaves glossy green above and white as snow beneath.

P-Volga or Russian Poplar. Extremely hardy, and of remarkably rapid growth. The beautiful glossy foliage hangs till late, and assumes a handsome golden tint.

PFRSICA-Peach. In May every branch is bright with flowers, rendering the tree attractive at a great distance.

P-Vulgaris, Var. Alba $\mathbf{F l}$. Pl. Double White-Flowering Peach. Superb buds and blooms of purest white. 4-6 ft., $\$ 1.00$.

VAR. SANGUINEA FI. FI.-Double Red-Flowering Peach. Semi-double flowers of bright red. A brilliant contrast for grouping with the above. $\$ 1.00$.

PTFIFA TRIEOIATA-Hop Tree. A dwarf-growing shrub-like tree, bearing large clusters of seeds resembling hops. $6-8 \mathrm{ft}$., $\$ 1.00$.

P-Trifoliata Aurea. Golden Hop Tree. A distinct, golden variety, with fine, yellow foliage, retaining its color well in summer. 3-4 ft., \$1.00.

PYRUS ANGUSTIOIIA - Bechtel's Double-Flowered Crab. One of the finest flowering Crab Apples, of medium size. covered in spring with large double fragrant flowers of a delicate pink, resembling roses. 3-4 ft., 75 c. 
QUERCUS AIBA-White Oak. The noblest tree of eastern American forests, retaining its vigor unimpaired and increasing in grandeur for centuries. 6-8 ft., $\$ 1.50$.

Q-Coccinea. Scarlet Oak. The autumnal tints of the foliage are exceedingly bright and beautiful. 6-8 ft., $\$ 1.50$.

Q-Falustris. Pin oak. Foliage finely cut, witl a drooping habit. One of the fastest growing oaks. $6-8 \mathrm{ft}$., $\$ 1.50$.

SAIISBURIA-Maiden-Hair Tree, or Gingko. A choice tree from Japan, of medium size, rapid growth, with beautiful foliage. Resembling the MaidenHair Fern. 6-8 ft., $\$ 1.50$; 8-10 ft., $\$ 2.00$.

SOREUS AUCUPARIA-Mountain Ash. A fine, hardy tree, head dense and regular; covered from July with bright scarlet berries.

SAIIX-Wisconsin Weeping Willow. Of drooping: habit. Valuable on account of its ability to resict severe cold.

S-Caprea Pendula. Kilmarnock Weeping Willow. A graceful tree, with glossy folizge and perfect umbrella head, thriving in all soils. 5-6 ft., \$1.00.

S-Thurlow Weeping Willow. Erect rapid growth of stem with very drooping branches. Similar in habit to the cut-leaf birch. Very hardy.

S-Aurea. A fine tree at all seasons, but very showy in the winter months for its bright yellow bark.

s-Iaurifolia. Laurel-Leaved Willow. A beautiful, distinct, medium-sized tree, 8 to 20 feet high, with shining, laurellike leaves.

TIIIA AMERICAN-American Linden. A rapid-growing large-sized, beautiful native tree, wjth very large leaves.

I-Argentea. White or Silver-Leaved Linden. A handsome, vioorous growing tree; pyramidal form: large leaves, whiti h on the under side. 6-s ft., e1.5r.

UI VTTS AMERICANA-American White Flm. The well-known noble tree, of our own fore ts; the most beautiful of all our native trees for street and lawn. 10-12 ft., \$2.00; $12-14$ ft., \$2.50.

U-Fendula. Camperdown Weeping. A drooping variety of the Scotch Elm. Verv handsome, rich, dark foliage, and luxuriant growth. A broad, low, drooping habit. \$2,00.

U-Aurea. Golden-Leaved Elm. A beautiful variety, with bright golden leqves. Promises to be a great acquisition. $\$ 2.50$.

U- Euntingdoni. Huntingdon Eln. A fine variety of the Scotch Elm, with large leaves and vigorous growth; very erect. 6-8 ft.. \$2.00; 8-10 ft., \$2.50.

U-Purpurea. Purple-Leaved EJm. A variety of the English Elm. having small purple leaves; of upright vigorous, hardy growth. $6-8 \mathrm{ft}$., $\$ 2.00$; 8-10 ft., \$2.5ก.

VIBGIIIA IUT'EA-Yellow Wood. Of medium height; with round head; light green foliage. Fragrant pea-shaped flowers in long bunches in June. 4-5 ft., $\$ 1.50$.

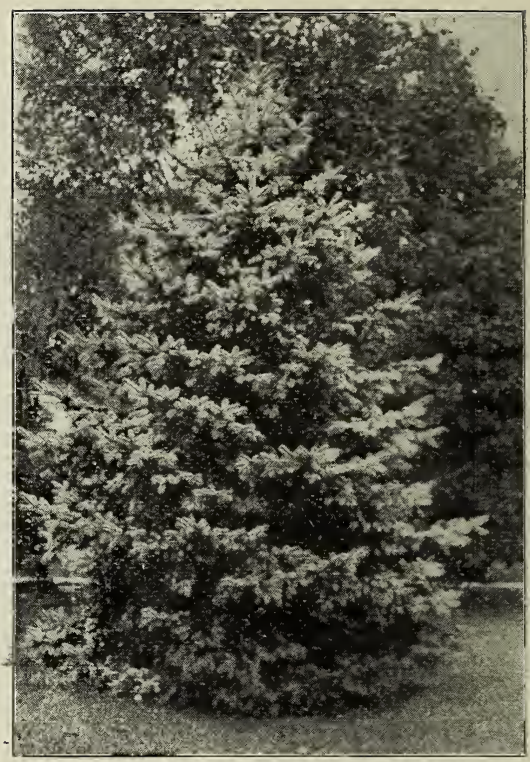

\section{Colorado Blue Spruce.}

ABIFS FZCEISA-Norway Spruce. Of lofty, rapid growth, and pyramidal form. One of the most popular evergreens for planting singly or in masses for shelter or for hedges. $3-4 \mathrm{ft}$., 75c; 4-5 ft., \$1.00.

A-Pungens Glauca. Colorado Blue Spruce. One of the hardiest and most beautiful of all the Spruces; in form and habit similar to the White Spruce; foliage of a rich blue or sage color; an important acquisition. $2 \mathrm{ft}$, \$2.50; $3 \mathrm{ft} ., \$ 3.50$.

A-Douglasii. Douglas' Spruce. From Colorado. Large conical form; branches spreading, horizontal; leaves light green above, glaucous below, 3-4 ft., $\$ 1.50$.

A-Balsamea. Balsam Fir. A very erect, regular pyramidal tree, with dark green somber foliage. Grows rapidly and is very hardy. 3-4 ft., $\$ \mathbf{1 . 0 0}$.

A-Canadensis. Hemlock. An elegant pyramidal tree, with drooping branche $;$ and delicate dark foliage, like that of the Yew, distinct from all other trees. It is a beautiful lawn tree, and makes a highly ornamental hedge. $2-3$ ft., \$1.00; 3-4 ft., \$1.50; 4-5 ft., \$2.00.

THUJA OCCIDENTATIS-American Arbor Vitae. Our well-known native variety so much used for hedges. Of conical, rapid growth, and much beauty. 2-3 ft., 50c; 3-4 ft., 75c; $4-5$ ft., $\$ 1.00$. 
T-Aurea. Douglas' Golden Arbor Vitae. Free grower with fine golden yellow foliage; hardy; the most desirable Golden Arbor Vitae for the northern States. 2-3 ft., $\$ 1.00 ; 3-4$ ft., $\$ 1.50$.

T-Siberica. Siberian Arbor Vitae.. Exceedingly hardy; growth compact and pyramidal, makes an elegant lawn tree; of great value for screens and hedges. 2-3 ft., \$1.00.

FIN]S SYIVFSTRIS-Scotch Pine or Fir. A native of the British Islands. A fine, robust, rapid-growing tree, with stout, erect shoots, and silvery green foliage. Very hardy; valuable for shelter. 2-3 ft., 5cc; $3-4$ ft., $\$ 1.00 ; 4-5$ ft., $\$ 1.50$.

P-Mugho. Mountain or Dwarf Pine. Does not grow tall, assuming a globular form; fine for evergreen shrubbery. 5C.c and $\$ 1.00$ each.

P-jtrobus. White Pine. Tall, stately and most beautiful of all our native Pines, reaching a height of 120 feet. It is also among the quickest-growing, long-lived, and most generally useful. 2-3 ft., 5ic; 3-4 ft., 75c; 4-5 ft., $\$ 1.00$.

\section{FIFTY THOUSAND PEONIES}

\section{IN CHOICE NAMED VARIETIFS.}

By close observation and a careful selection of the best sorts offered, we have approximated our conception of a choice collection. For fifteen years we have been doing this and our list comprises the sum of our efforts.

NAMED VARIFTIFS. Our selection, dozen, \$4.00; per hundred, 25.c0.

\section{Strong Roots of Three to Five Eyes Fach.}

No. 46. ACFIIIF. Blush white, changing to white when open. Early. Fragrant, and a free bloomer. Each, 30c; per doz., \$3.00.

NO. 8. BARONFSS SCFROFDER. A most delicate light flesh pink bud, bleaching when open to white, extra large and massive. \$2.50 each; $\$ 25.00$ per doz.

No. 26. SHRYSANTHI-FIORA. Very early, delicate bloom, with blush guard petals, and lemon yellow center. Each, 35c; dozen, \$3.00.

No. 3. COQUETrg. Delicate rose guard petals; center of cream and rose. Beautiful and early. Each, 40c; dozen, \$4.C0.

No. 21. COURONAE D'OR. Large blooms of ivory white, with a circle of yellow which suggests the name. An extra tine sort. Blooms rather late. Each, 50c; dozen, \$5.00.

No. 34. DEIACFI. Brilliant deep crimson. Very full and double, intersper sed with yellow stamens. Late in flowering. Each, 30c; dozen, \$3.00.
No. 48. EDJIIJ-3UPझRBA. Vivid deep rose. Full rouided fragrant flower, and early bloomer. Each, 3ic; dozen, $\$ 3.00$.

No. 11. EUGENIF VERDIER. One of the showiest and most beautiful pink varieties. Very large, 40 inches tall, very free bloomer. Delicate pale flesh pink. Each, 4Cc; dozen, \$4.00.

No. 9. FEIIX CROESSE. Bright red bomb, distinct color, very large and massive, very free, grand in every way. An absolutely indispensable variety. Each, 50c; dozen, \$5.00.

No. 19. FFSTIA. Pure waxy white with carmine spots at center, large and medium late. One of the best whites. Each, 40c; dozen, $\$ 4.00$.

No. 45. FIORAI TREASURE. Clear light pink. Strong habit and free bloomer. A fine variety for cutting. Each, 40c; dozen, \$4.c.C.

No. 27. 'FESTIVA IMAXIMA. One of the choicest peonies grown. Clear white with carmine spots at center. Immense flower on a very sirong stem. Each, 50c; dozen, \$5.00.

No. 44. GOIDEN HARVIST. Outer or guard petals blush white, center yellow and white tipped with crimson. Each, 4Cc; dozen, $\$ 4.00$.

No. 49. GRANDIFIORA RUBRA. Late. i)ep red in color; very large bloom, equaling Festiva Maxima in size. Each, 40c; dozen, \$4.00.

No. 22. FUIMEI. Brilliant solid pink. Very large size and one of the latest to bloom. Each, 25c; dozen, $\$ 2.50$.

No. 2. IADY BRAIMWEII. Silvery rose, solid color, large guard, rosette shape. Fragrant, good keeper. Each, 3uc; dozen, \$3.00.

No. 38. IAMARTINE. Known also as Giganthea. Clear, light silvery pink, of rose shape. Large and full and very free on old plants. Spicy fragrance. One of the best early pinks. Each, 35c; dozen, $\$ \mathbf{3 . 5 0}$.

No. 47. IA TUIIPE. Blush white with outer netals flaked carmine, making a tulip effect. Each, 40c; dozen, \$4.00.

No. 28. MADAIME BUCQUET. Dark maroon purple, beautiful bud, large blooin, very free bloomer. The best dark red, with very few stamens. Each, 3uc; dozen, \$3.00.

No. 4] MAD. CROUssE. Pure white large flower, beautiful bud, strong erect grower; one of the best for cut flowers. Each, 35c; dozen, \$3.50.

No. 40. MADAME DE VERIEVIIIE. Une of the most beautiful varieties we have. Pure white with faint blush tint in center; very delicate, early, free, and exceptionally fragrant. Each, 50c; dozen, \$5.c0. 
No. 43. MISIE IEMOINE. The latest white to bloom, thus extending the seasun after earlier ones are passed. Immenso ivory white blooms un very strong stems. Each, 40c; dozen, \$4.00,

No. 10. NI IIUS UITRA. Large well rounded flower of clear peach tinted rove. Strong habit and free bloomer. Fach, 25c; dozen, \$2.5c.

No. 25. OEFICINAIIS RUBRA. Commonly known as Early Red. Bright crimson. A week earlier than other varieties. Fach, 25c; dozen, \$2.50.

No. 4. OUFEN VICTORIA. Blush white guard petals, and creamy white center. A full large bloom. Medium early and a good keeper. Each, 35c; dozen, \$3.00.

No. 50. RICHARD SON'S RURRA SUPFBBA. Deep glowing crimson with purple shading. Each, 50c; dozen, $\$ 5.00$.

No. 1. ROSEA-EIEGAN?. Solid color of beautiful deep cherry rose. Large full blcom, supported by a tall strong stem. An early variety. Each, 30c; dozen. \$3.co.

No. 5. RT?RA TRIJMPEA INS. Large rich bloon of brilliant crimson. A choice medium early variety. Each, 3En. anzen ez.ne.

No. 31. SOUV. DE I'EXFOSITIOIN. Fine c'ear shade, lizht-rose, globe shaped, good sized. tall and free, fragrant and early. Each, 3Jo; dozen, \$3.00.

No. 37. Beautiful large deep pink with rarmine tints. A choice tall-growing variety. Each, 25c; dozen, 32.50.

No. 24. Full well-formed blooin of a delirate ivory white. Dwarf habit and medium late. Each, 30c; dozen, \$3.00.

No. 13. Delicate tint of carmine rose. very large. A late bloomer. Each, 3c.; dozen, \$3.00.

No. 7. Deep rose approaching crimson, with yellow tamers interspersed, large full bloom. Each, 40c; dozen, $\$ 4.00$.

No. 18. A beautiful flover in pure white. Tall and statelv. Full petaled and strong vioorous habit. A late variety. Each, 25c; dozen, \$2.50.

Nc. 12. Magnificent large bloom of bright roce. Fill round form. Strong habit. Fach, 35c; dozen, \$3.00.

No. 6. Guard petals bright rose with salmon circle or collar. and center of rose. Very strong orower and large blocm. Each, 35c; dozen, \$3.00.

No. 32. I arge bloom or brilliant rose, delicately flaked with carmine. A beauty. Each, 25c; dozen, \$2.50.

\section{HARDY PERENNIALS.}

Price except where noted, $\$ \mathbf{1 . 5 0}$ dozen; $\$ 10.00$ per hundred.

DEIPIINUM FORMOJ̈UM IARKSPUR. Tall spikes of bloom in shades of clear blue.

DIRTYTRA SPFC-Bleeding Heart. Delicate crimson and white heartshaped flowers.
EEIAIIA ZEBRINA-A beautiful grass, with zebra-striped foliage.

I-Zracilima. A new grass, with graceful narrow foliage.

FU MIA AIBA-Fragrant white day Lily, with handsome broad foliage. 25c each; $\$ 2.50$ dozen.

FEVEI OCAIIIS KWANSO - D o u b 1 e day Lilies of a bright orange yellow; each petal is marked with a large crimson blotch.

I- Flava. Lemon yellow; very fragrant day Lily.

I-Thun, flowers, a month later than Flava.

$\mathbf{Y}$ CiCA-Filamentosa. White, w a x y blooms in large panicles, sword-shaped foliąe. 25c each; $\$ 2.50$ dozen.

IIBISOU-Crimson Eye. Very large white flowers, with crim on eye.

FO blooms, measuring 6 to 8 inches across.

RUDEFCKIA-Golden Glow. A tall, hardy perennial, covered through late summer with double golden yellow blooms.

\section{GEMUAN IRIS-Fleur-de-Iis or Flag}

Price, excent where noted, \$1.50 per doz., \$10.0C per hundred.

NT “s" refers to the three standard or upright curling petals. "F" refers to the three falls or drooping petals.

Eridesmaid. "S" White shaded with silvery lilac. " $\mathrm{F}$ ", Reticulated at the base and slightly frilled, soft lilac.

Celeste. Fine satiny blue. One of the most beautiful, highly recommended for cut flowers.

Charles Dickens. “ $\mathrm{S}$ " Blue. “ $\mathrm{F}$ " Dark blue, suffused and veined dark purple.

Darius. " $\mathrm{S}$ " Lemon yellow, “ F" Purple, bleaching on edge and top to pale yellow, large; 30 in.

King cf Iris. " $\mathrm{S}$ " Lemon yellow. " $\mathrm{F}$ ", Leep brown and yellow. The best Iris to date; 24 in.

mme. Chereau. " $\mathrm{S}$ " and " $\mathrm{F}$ " White; daintily edged with porcelain blue. The prettiest and tallest of all; $40 \mathrm{in}$.

Maori ring. "S" Golden yellow. " $\mathrm{F}$ "; Rich velvet crimson edged yellow; 14 in.

Mars. " $\mathrm{S}$ " Light yellow. "F" Pale yellow, blotched and veined violet.

Irs. I. Darwin. " $\mathrm{S}$ " Clear waxy white. " $F$ " White, violet veins; 24 in.

Penelcpe. "S" Pure white. " $F$ " White, di $₹$ tinctly veined purple, crested golden yellow.

Queen of May. " $\mathrm{S}$ " Lilac pink. " $\mathrm{F}$ " Lilac. blended with white.

sambucina. " $\mathrm{S}$ " Coppery rose. " $\mathrm{F}$ " Rosy purple with orange crest; 30 in.

Sans Souci. " $\mathrm{S}$ " Golden yellow. " $\mathrm{F}$, Yellow veined with crimson brown; 30 in.

Trautlieb. Of purest clear rose, shading to white towards the center of the flower. 


\section{HARDY PERENNIALS}

JAPAN IRIS-Iris Kaempferi.

I-IRAFMFF ERII. New Japan Iris. Beautiful color s strikingly mingled. $\$ \mathbf{2 . 0 0}$ dozen; $\$ 15.00$ hundred.

Blue Jay. Fine azure blue, freely mottled.

Crystal. Double pale violet.

Eclaire. Largest white.

Norma. Very deep lavender, double.

Faragon. Rich velvety purple; center marked with orange, very distinct.

Frincess Clothilde. Double, light blue.

spctted Feauty. Large size, very double, silky white, freely and finely dotted with violet crimson.

victor. Violet purple, with white veins.

IRIS-Siberica Orientalis-"Yale Blue" Doz.,\$1.50; per 100, \$10.00.

Strong, free-growing Iris, adapted to almost any position, producing a mass of deep blue flowers under the most adverse conditions from June to August.

\section{HARDY PHLOX.}

Among the best hardy plants for the decoration of the garden. Of dwarf habit, perfectly hardy, of easy culture. Dozen, \$2.00; per hundred, \$12.00.

PRICE-(Except where noted), onefyear field-orgwn, each, 1cא; per doz 85c; per 10\%, \$6.00; per $1000, \$ 55.00 / 25$ of any ghe variety af the $100, \mathrm{r} / \mathrm{te} ; 250$ at tbe 1,000 rate.

Baron Von Dedem ( $T$ 2). Blood-red scarlet with immense trusses and large individual flowers.

Eridesmaid (D 2). Pure white with large crimson-carmine eye; very fine.

Clara Benz (M 2). Brilliant carmine l'ose.

Frau Ant. Bushner (D 2). New. Pure white. Undoubtedly the finest white today. Strong habit. Very desirable.

G. A. Strohlein (M 2). Glowing orange scarlet with blood-red eye. Immense head.

General Von Fentz (M 2). Brilliant salinon-red with white eenter.

Gruppen Koenigin (M 2). Flesh with dark eye. Immense heads; very large individual flowers, very free and lasting.

I'Aiglon ( $T$ 1). One of the best of the deep rose varieties; bright carmine eye.

IMme. Faul Dutrie (M 1). Soft pink, suffused white. Very fine.

R. P. Struthers ( $\mathrm{T} 2$ ). Rosy carmine with claret eye. Very bright.

Selma (T 2). Large trusses of large pink flowers with cherry-red eye, Ixtra fine.

Sigrid Arnoldson. Fiery carmine rea with dark center. Extra choice.

Von Goethe (D 2). Pure clear pink with white eye. Very beautiful.

Von Hochberg (M 2). The ideal crimson. The richest of its color. One of the best.
FRUIT TREES

\section{APFIES. Each, $50 \mathrm{c}$ to $\$ 1.00$.}

Keswick Codlin. Large, yellow; pleasant acid; bears young, and abundantly. July to October.

Red Astrachan. Large, deep crimson, very handsome; juicy, good, though rather acid. Esteemed for its earliness and hardiness. August.

Duchess of oldenburg. Streaked red and yellow; tender, juicy and pleasant; a vigorous grower. September.

Fameuse. Snow Apple. Medium size; deep crimson; flesh snowy white, tender and delicious. November.

wealthy. Dark red; flesh white, juicy, sub-acid, very good. Tree very hardy. October.

Golęn Zusset. Crisp, juicy and high flavored; a vigorous grower. November to April.

Grimes Golden. Golden yellow; tender, juicy, sprightly; very good to best. January to April.

Jonathan. Red and yellow; tender, juicy and rich; very productive. November to March.

Tompkins King.. A superb red apple of the largest and finest quality. November to January.

Crab Apples. Very ornamental when in bloom, and in fall, when laden with fruit. Each, $50 \mathrm{c}$ to $\$ 1.00$.

Northern \$py. Large; striped, crimson next the sun; juicy, rich and aromatic, retaining these qualities until late spring or summer. A fast grower.

*Northwestern Greening. Like Grimes' Folden in shape and color; of good flavor; keeps long. Tree hardy and vigorous.

Delicious. A new apple of rare merit. rolor a brilliant dark red blending with yellow. Sweet with a slight acid flavor, "fine grained and very juicy. Very large fruit of bellflower form. $\$ 1.00$ each; $\$ 10.00$ dozen.

PEARS. Each, $75 \mathrm{c}$ to $\$ 1.00$.

Bartlett. On $\theta$ of the most popular pears; large, buttery and melting, with a rich musky flavor. Middle to last of September.

BEIUE IUCRATIVE. Large, melting and sweet; bears early and abundantly. September and October.

Clairgeau. Very large, yellow and red; handsome and attractive; keeps sound a long time; a magnificent fruit. October.

Clapp's Favorite. A splendid pear, resembling the Bartlett and ripening a few days earlier; hardy and vigorous. September.

Flemish Beauty. A large, beautiful, melting, sweet pear; very hardy, vigorous and fruitful. September and October.

Kieffer. Of extraordinary size and beauty. While not of the best quality, it is one of the favorite sorts for canning.

Iouise Bonne of Jersey. A large, beautiful, first-rate pear; yellow with a dark red cheek; a vigorous, erect grower. September and October. 


\section{FRUIT TREES AND SMALL FRUITS.}

Sheldon. A large, round russet-and-red Pear of the very first quality. Hardy, free-growing, fruitful. October.

worden-Seckel. Resembles Seckel in quality and flavor, and surpasses in size and beauty. Equally delicious. October.

wilder. One of the very earliest Pears, attractively colored and of excellent quality. Of medium size, pale yellow, with shadings of russet-red; flesh melting and delightful, with small core. Early August.

JAPANISF PIUIMS. Fach 75 to $\$ 1.00$.

Abundance. Amber, with markings of red; juicy, sweet, of good quality. May be picked when it begins to color.

Eurbank. The fruit is large, nearly round and bright cherry-red. Its deep yellow flesh is sweet and firm.

satsuma (Blood). A delicious Plum for canning, and a grand market sort. Very laroe. nearly round, with deep red skin and flesh.

\section{PFACFES 50 to $75 \mathrm{c}$ Fach.}

Crawferd's Farly. A magnificent large yellow Peach, noted for iize. good quality and wonderful productiveness. $T$ ate August.

Fubrta. A leading market variety. Fruit is large, hand =ome bright yellow, overspread with crimson; juicy, good. August and September.

May"ower. A most beautiful Peach, bright red all over and of good size. Fxtremelv early. Tree is a strong, thrifty grower.

Yellow st. John. A superfine early yelInv freestrne, nearly as large as Crawford $a=$ fine' $^{7} \mathrm{col}$ cred and of even better flavor. August.

\section{CHERRIES. Iach 50c to $\$ 1.00$.}

Farly Richmond. The standard sort for this section.

wragr. Medium to large: blackish; rich acid, and good. very productive, and very hardv. Jily.

Iarge Montmorency. Larger and finer than Farly Richmond, and one of the finest flavored Cherries in this class. The strong, hardy tree makes rapid growth and bears enormous crops.

\section{QUINCE. 75c Each.}

Apple. or Orarge. The best of the older varieties, still more extensively cultivated than any other. Its large, roundish fruits ripen in October.

Bourreat. Frints of the largest size, round, smooth, of bright golden color, with small core. Exceeds all others in fruitfulness.

\section{STRAWBFRRIFS.}

All of these Strawberries are perfect flower varieties. $\$ 1.00$ per $100 ; \$ \mathbf{\$ 8 . 0 0}$ ner 1.000 .

rick Ohmer. A fine, fancy market berry and always superb for the table. A giant in size; it is yet deep red all through; globular, high-flavored, delicious.
Wm. Belt. Luxuriant grower; very productive of large, brilliant, red fruit, without green tips. Very fine quality.

Senator Dunlap. A large, regular, and attractive berry deep red in color and exceedingly firm in substance and excellent in quality. One of the very early sorts and continues in bearing nearly a month.

CURRAITTS. Fach, 15c; Dozen, \$1.50.

Fay's Prolific. A new red sort; surpasses all others.

white Grape. Very large; white, mild and excellent.

\section{GOOSFBFRRIFS. Fach, 15c; Dozen,} $\$ 1.50$.

Downing. Very large, handsome, pale green; splendid and productive.

Red Jacket. A new American variety; very productive, hardy; excellent quality, and proof against mildew. 25c; $\$ 2.50$ per dozell.

RASPBERRIFS. Each, 15c; Dozen, \$1.50.

Cuthbert. Very hardy, prolific; fruit brilliant red, excellent.

Cumberland. The largest blackcap. A vigorous grower, throwing up stout, stocky canes, bearing loads of luscious fruit.

Ioudon. Very hardy and vigorous; ripens with the Cuthbert, and continues longer. Berries larger and firmer. Very productive.

\section{BIACKBgRRIFS. Fach, 15c; Dozen, $\$ 1.50$.}

Fldorato. Of large size and delicious quality. Extremely hardy and prolific.

\section{GRAPES. Fach, 25c; Dozen, \$2.50.}

Erighton. In color, form of bunch and berry, resembles Catawba, has the richness and sweetness of Delaware; vine vigorous, hardy and productive.

Campbell's Farly. Strong, vigorous, hardy vine; heavy foliage; abundant crops; very large, handsome clusters. Season very early. A good keeper and shipper. Berries large, nearly round; black, with light purple bloom; skin thin.

Concord. Purplish black a standard sort. Two years.

Niagara. Remarkably hardy and strong grower; bunches large and compact: berries light oreenish white, semitransparent, slightly ambered in the sun; melting and sweet to the center.

Pockington. A light golden yellow, clear juicy and sweet, with little pulp; bunches large, and thickly set; quality much superior to Concord. The best of a.l1 white grapes.

wyoming Red. A decidedly fine, early red Grape. Bunch and berry double the size of Delaware, of same color, and resembles it in flavor. Ripens a week or ten days before Concord. 
This Booklet is issued in the hope that it contains some helpful information and suggestions toward making the "outdoors" of a home a source of greater interest and delight the year round. It aims plainly to state the fundamentals of the business of planting and to give facts that are learned by the average consumer only through years of costly experience.

We feel that a mere catalog of genera, species, varieties, and other technical details is of little interest to the average landholder. Hence we have tried to include a reasonable explanation of why and how we can help him and the way we should go about it.

The reproductions shown herewith are from photographs taken specially for our use and, with one or two exceptions, of our own plantings.

For prices, see in the catalog at the head of each class listed,-price of shrubs at head of shrub list, etc.

GUARANTEE. We do not guarantee stock unless by special agreement and planted by ourselves. When planted it becomes the duty and privilege of the buyer to give it all needed attention whether guaranteed or not.

With an order of $\$ 25$ and upwards we will replant any stock that dies within one year from date of bill if such agreement is made at time of sale and provided the following cultural instructions are followed. We are led to print these conditions through the utter neglect of our plantings in some cases, and the blame to which we are subjected for the failures which are the natural consequence.

CULTIVATION.-For a year after planting all stock must be kept free from grass and weeds, and the soil kept loose with hoe or spade.

WATERING.-In a diy summer all stock must be watered thoroughly at least twice a month;-a good soaking that reaches the roots.

STRAIGHTENING.-Newly planted trees and tall shrubs are thrown out of plumb by a heavy storm. These must be straightened and the earth about them firmed again.

Visit us at the nurseries on any week day. We are not open for business on Sundays. We are always ready to make an appointment with any wishing to con. sult us either at their home, city office, or at our nurseries. Address us

\section{JAMES KING NURSERY \\ HORTICULTURISTS AND LANDSCAPE GARDENERS}

ELMHURST AND WHEATON, ILL.

Phones-Elmhurst 102-M-Wheaton 298.

Established 1890 . 


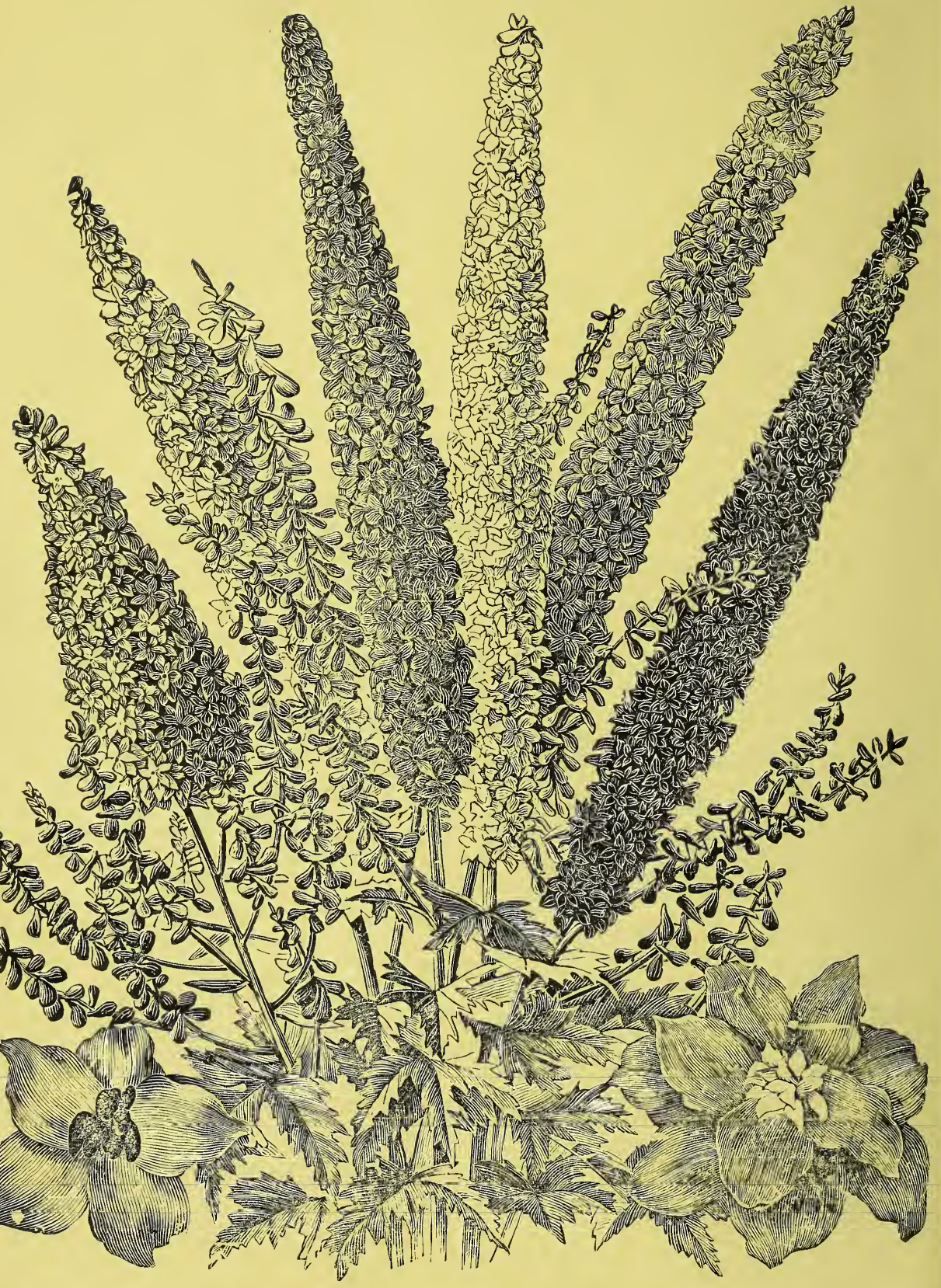

DELPHINIUM FORMOSUM-See Page 14 